UCRL-ID-127172

\title{
Uranium Alloy Forming Process Research
}

T. S. Chow, T. A. Biesiada, A. Sunwoo, J. Long,

T. Anklam, S. W. Kang

March 1, 1997

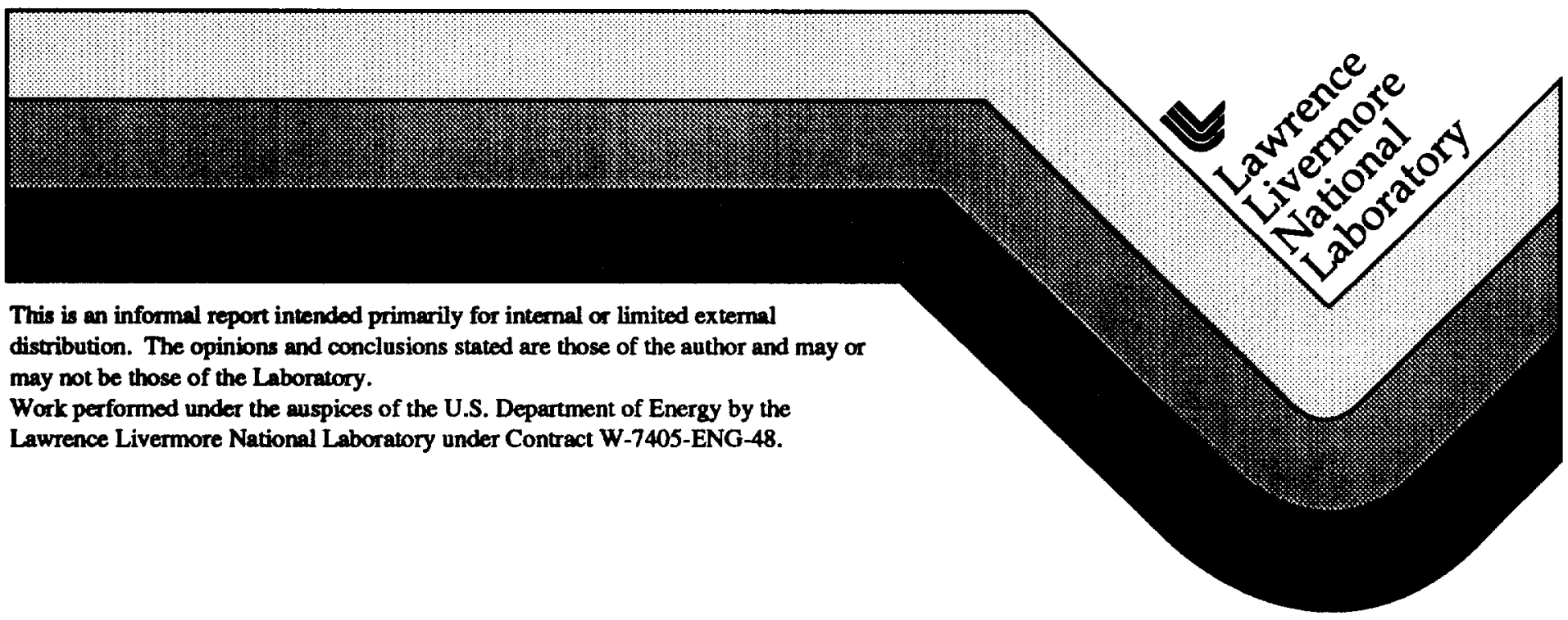




\section{DISCLAIMER}

This document was prepared as an account of work sponsored by an agency of the United States Government. Neither the United States Government nor the University of California nor any of their employees, makes any warranty, express or implied, or assumes any legal liability or responsibility for the accuracy, completeness, or usefulness of any information, apparatus, product, or process disclosed, or represents that its use would not infringe privately owned rights. Reference herein to any specific commercial products, process, or service by trade name, trademark, manufacturer, or otherwise, does not necessarily constitute or imply its endorsement, recommendation, or favoring by the United States Government or the University of California. The views and opinions of authors expressed herein do not necessarily state or refiect those of the United States Government or the University of California, and shall not be used for advertising or product endorsement purposes.

This report has been reproduced directly from the best avallable copy.

Available to DOE and DOE contractors from the

Office of Scientific and Technical Information

P.O. Box 62, Oak Ridge, TN 37831

Prices available from (615) 576-8401, FTS 626-8401

Available to the public from the

National Technical Information Service

US. Department of Commerce

5285 Port Rojal Rd.

Springfield, VA 22161 


\title{
LDRD (96-ERD-016) Final Report
}

\section{Uranium Alloy Forming Process Research}

\author{
March 1997 \\ Principal Investigator: T. S. Chow \\ L-Code: L-125 \\ Co-Investigator: T. A. Biesiada \\ Email: chow4@llnl.gov \\ L-Code: L-460 \\ Tel: (510) 422-4639 \\ FAX: (510) 423-4097 \\ Email: biesiada@1lnl.gov \\ Tel: (510) 422-9258 \\ FAX: (510) 423-1460
}

\section{A. Sunwoo/DTED \\ J. Long/ISAM \\ T. Anklam /ISAM \\ S. W. Kang/NTED}

with support of
Metallurgy
Metallurgy
Engineering
Modeling/KEM

\begin{abstract}
The study of modern $\mathrm{U}-6 \mathrm{Nb}$ processes is motivated by the needs to reduce fabrication costs and to improve efficiency in material usage. We have studied two potential options: (1) physical vapor deposition (PVD) for manufacturing near-net-shape U-6 Nb, and (2) kinetic-energy metallization (KEM) as a supplemental process for refurbishing recycled parts. In FY 1996, we completed (1) two series of PVD runs and heat treatment analyses, (2) the characterization of the microstructure and mechanical properties, (3) a comparison of the results to data for wrought-processed material, (4) and experimental demonstration of the KEM feasibility process with a wide range of variables (particle materials and sizes, gases and gas pressures, and substrate materials), and (5) computer modeling calculations.
\end{abstract}

\section{Description of Technologies and Goals}

Physical Vapor Deposition (PVD)--This research examines the effects of PVD process variables and the supplemental process steps to validate the experimental findings already in hand and to improve the understanding of the microstructure characteristics of the PVD deposit. The goals are to lay a foundation for fabrication of hydro-test samples and to develop a PVD-based process for full scale manufacturing.

The key technical issues to be addressed are the improvement of composition homogeneity, and, consequently, control of the microstructure and mechanical properties of PVD material. The areas to be studied are the PVD process variables including ion bombardment during deposition, substrate temperature, and feed control; and subsequent material processing such as the optimization of heat treatment for the PVD material.

Kinetic Energy Metallization (KEM)--As a supplementary process for refurbishment/repair or creation of physical discontinuities for the blanks made by such process as PVD, the goal of this study is to establish feasibility using surrogate powder materials. An outside contractor (Innovative Technology Inc. (ITI)) is contracted to perform the experiments. As a background, ITI, who has the proprietary claim to the technology, first observed the KEM phenomena in a supersonic particle ignition study, and has since demonstrated its feasibility with a series of laboratory experiments. Typical process parameters to be 
studied are: carrier gas type and pressure, powder materials (type and size), impact velocity, and target materials. Modeling will be included to enhance understanding of the process, and has been done under a separate funding source.

\section{Project Plan}

The project plan is summarized in the following table.

\begin{tabular}{|c|c|c|}
\hline Deliverables & Objectives & Achievements \\
\hline \multicolumn{3}{|l|}{ PVD } \\
\hline $\begin{array}{l}\text { testing existing PVD } \\
\text { samples from run \#3 }\end{array}$ & $\begin{array}{l}\text { - build database and } \\
\text { provide compare } \\
\text { with wrought } \\
\text { processed material } \\
\text { - optimizing the } \\
\text { process }\end{array}$ & $\begin{array}{l}\text { - heat treatment } \\
\text { - tensile tests } \\
\text { - metallurgy } \\
\text { - Auger scan } \\
\text { - carbon analysis } \\
\text { - deformation due to heat treatment: } \\
\text { completed } \\
\text { - } \text { shape memory: completed but results } \\
\text { inconclusive } \\
\text { - } \text { surface composition mapping } \\
\end{array}$ \\
\hline - PVD experiments & $\begin{array}{l}\text { process optimization } \\
\text { for microstructure } \\
\text { and properties } \\
\text { including: substrate } \\
\text { temperature, ion } \\
\text { bombardment }\end{array}$ & $\begin{array}{l}5 \text { Mars runs completed, } 3 \text { short- } \\
\text { duration, two long-duration; } 3 \text { thick } \\
\text { samples obtained: Mars } \# 7-700^{\circ} \mathrm{C} \\
\text { substrates temperature with } \\
\text { enhanced ionization, and Mars } \# 9 \text { - } \\
600 \text { and } 700^{\circ} \mathrm{C} \text { substrate } \\
\text { temperatures with no ionization. }\end{array}$ \\
\hline - testing new PVD samples & & $\begin{array}{l}\text { - \#4-\#6 samples optically } \\
\text { micrographyed } \\
\text { - \#7 sample fully analyzed } \\
\text { - \#9 samples optically micrographed }\end{array}$ \\
\hline \multicolumn{3}{|r|}{ 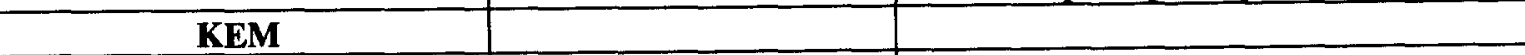 } \\
\hline $\begin{array}{l}\text { - deposition experiments } \\
\text { consisting of parameters: } \\
\text { powder material, substrate, } \\
\text { powder size, gas pressure } \\
\text { (100-450 psig), and gas: } \\
\text { helium or nitrogen } \\
\end{array}$ & $\begin{array}{l}\text { to demonstrate the } \\
\text { KEM process } \\
\text { feasibility }\end{array}$ & $\begin{array}{l}\text { KEM runs at ITI completed } \\
\text { - mechanical test of KEM samples } \\
\text { completed. } \\
\text { - modeling using CALE computer code } \\
\text { in progress, funded under other } \\
\text { source }\end{array}$ \\
\hline progress reporting & & JOWOC31 meeting in May 96 \\
\hline $\begin{array}{l}\text { process modeling and system } \\
\text { analysis }\end{array}$ & $\begin{array}{l}\text { cold and hot work } \\
\text { process simulation }\end{array}$ & preliminary results \\
\hline Reporting & & reports and (refereed) Journal accepted \\
\hline
\end{tabular}

\section{Accomplishments}

We have accomplished the following:

- Completed 5 PVD runs to refine the process consisting of such parameters as substrate temperature, ion enhancement, and vapor flux density.

- Characterize microstructure and tensile properties of the samples from previous and most current runs.

- Compare the properties and characteristics of the PVD alloy with those from the conventional (wrought) processed alloy.

- KEM experiments and data analysis.

- Publications. 


\section{A.1 PVD Experimental Setup}

The setup (Figure 1) consists of an electron beam gun; a bottom-fed water-cooled crucible; thermally controlled substrate(s); and a water-cooled vacuum chamber. The substrates were also electrically insulated so that a DC bias voltage could be imposed. In addition, a tantalum anode for ion-enhancement, and electrical hookup for the anode (500 amp at 30v) with electric insulation and grounding fixtures were also incorporated in the setup as shown for the current runs.

As the overhead E-beam melts the ingot from the crucible, the $\mathrm{U}$ and $\mathrm{Nb}$ vaporized and coated the substrates. Feedstock ingot was made by E-beam cold hearth melting and casting of $\mathrm{U}-6 \mathrm{Nb}$ forming scrap material. Since the scrap material was from a wrought-processed alloy, it is assumed that the ingot chemistry was within the specification of $5.2-6.5 \%$ wt- $\% \mathrm{Nb}$, and that there was no loss of $\mathrm{Nb}$ through vaporization process.

\section{A.2 PVD Sample Analyses}

The following table (Table A1) is a summary of (flat plate) runs from all Mars runs.

Table A1

\begin{tabular}{|c|c|c|c|c|c|c|l|}
\hline $\begin{array}{c}\text { Mars } \\
\text { Runs } \\
\#\end{array}$ & $\begin{array}{c}\text { temp } \\
{ }^{\circ} \mathrm{C}\end{array}$ & Bias KV & $\begin{array}{c}\text { Gun } \\
\text { Current, } \\
\text { ampere }\end{array}$ & $\begin{array}{c}\text { Vapor } \\
\text { Rate, } \\
\mathrm{kg} / \mathrm{hr}\end{array}$ & $\begin{array}{c}\text { Ion } \\
\%\end{array}$ & Substrate & \multicolumn{1}{|c|}{ Comments and Notes } \\
\hline 1 & 1050 & 0 & 4.0 & 4.7 & 0 & $\begin{array}{c}\text { aperture } \\
\text { plate }\end{array}$ & $\begin{array}{l}\text { pre-LDRD run: good properties, } \\
\text { columnar grains, some banding }\end{array}$ \\
\hline 3 & 900 & 0 & 5.3 & 5.1 & 0 & $\begin{array}{c}\text { aperture } \\
\text { plate }\end{array}$ & $\begin{array}{l}\text { pre-LDRD run: good properties, } \\
\text { columnar grains, micro-voids, } \\
\text { banding }\end{array}$ \\
\hline 3 & 580 & $0.15-0.5$ & 5.3 & 5.1 & 2 & roof & $\begin{array}{l}\text { pre-LDRD run: good properties, } \\
\text { smaller, equiaxed grains, sharp } \\
\text { banding }\end{array}$ \\
\hline 3 & 350 & $0.15-0.5$ & 5.3 & 5.1 & 2 & roof & pre-LDRD run: poor quality deposit \\
\hline 4 & & & & & & & $\begin{array}{l}\text { shakedown run for the current } \\
\text { LDRD matrix }\end{array}$ \\
\hline 5 & 710 & 1.5 & 4.0 & 3.6 & 5 & substrate & $\begin{array}{l}\text { 2 hour run: fully dense, smaller, } \\
\text { equiaxed grains, very sharp } \\
\text { banding }\end{array}$ \\
\hline 6 & 680 & 1.5 & 4.0 & 3.6 & 1 & substrate & 2 hour run: poor deposit \\
\hline 7 & 700 & 1.5 & 4.0 & 3.6 & 8 & substrate & $\begin{array}{l}\text { 5-1/2 hour run: good tensile } \\
\text { properties; some inclusions }\end{array}$ \\
\hline 9 & 580 & 0 & 5.5 & 6.6 & 0 & $\begin{array}{l}\text { roof and } \\
\text { substrate }\end{array}$ & $\begin{array}{l}\text { 6 hour run: 2 solid deposits } \\
\text { obtained (2-9/16"x5-3/16"x0.150") } \\
\text { from substrates at 600 and 700 }{ }^{\circ} \mathrm{C}, \\
\text { no bias nor ion enhancement; bias } \\
\text { was lost due to shorting; the } \\
\text { deposits on the roof substrates were } \\
\text { poor. Metallurgy pending. }\end{array}$ \\
\hline
\end{tabular}

Testing of PVD Samples from Previous Runs (run \#3) -- The heat treatment and mechanical testing of the PVD samples from run \#3 run were completed. These samples were produced using two different substrate temperatures, $580^{\circ} \mathrm{C}$ with 0.15 $0.5 \mathrm{KV}$ bias and $900^{\circ} \mathrm{C}$ without bias (identified as PVD 500b and PVD 1000u, respectively), consisting of 8 specimens. The alloy made with the substrate 
temperature at $580^{\circ} \mathrm{C}$ has substantially better combined tensile properties than the one made with the substrate temperature at $900^{\circ} \mathrm{C}$. With aging at $200^{\circ} \mathrm{C}$ for two hours, both sets of material showed a decrease in elongation but an increase in yield strength. However, at $-40^{\circ} \mathrm{C}$, elongation for the $580^{\circ} \mathrm{C}$ substrate material increased from $26 \%$ to $38 \%$, as shown in Table $\mathbf{A 2}$.

The microstructure characterization showed that the grains of PVD 500b are equiaxed and about $10-20 \mu \mathrm{m}$ in size with fine banding of $\mathrm{Nb}$-rich regions and $\mathrm{Nb}$-lean regions through the thickness. The microhardness trace across the bands indicates that the $\mathrm{Nb}$ rich region is much softer than the $\mathrm{Nb}$-lean region. Moreover, the size and volume fraction of the $\mathrm{Nb}$-rich phase precipitates in PVD 500b are considerably different from those of the PVD $1000 \mathrm{u}$. They were long and sparsely distributed in the uranium matrix, resulting in lower strength. Although the grains of PVD $1000 \mathrm{u}$ are columnar and an order of magnitude larger compared to PVD 500b, the Nb-rich phase precipitates are finely distributed in the uranium matrix, exhibiting higher strength and microhardness but lower elongation. In addition to the inverse relationship between the strength and the elongation, a lower elongation value is also attributed to the presence of voids along the boundaries. Because the material contains columnar grains, it may be quench sensitive, causing it to form voids along the boundaries to relieve thermal stresses. The causes of void formation will be further analyzed.

The tensile property values are compared with those of the wrought processed U6Nb alloy $(\mathrm{Y}-12)$ at room temperature and $-40^{\circ} \mathrm{C}$. The wrought specimens were standard cylindrical geometry, whereas the PVD specimens were flat "dog-bone" shape, with a $40 \%$ reduced gage thickness to ensure failure in the gage length.

Table A2

\begin{tabular}{|l|c|r|r|r|c|c|}
\hline Material ID & HT & $\begin{array}{c}\text { Test } \\
\left({ }^{\circ} \mathrm{C}\right)\end{array}$ & UTS (ksi) & YS (ksi) & $\begin{array}{c}\text { Elongation } \\
(\%)\end{array}$ & $\begin{array}{c}\text { E } \\
\left(\mathrm{x} 10^{6} \mathrm{psi}\right)\end{array}$ \\
\hline PVD 500b & $\gamma$-quench only & 25 & 126 & 22 & 40 & 9 \\
\hline PVD 500b & $\gamma$-quenched and aged & 25 & 130 & 51 & 26 & 9.9 \\
\hline PVD 500b & $\gamma$-quenched and aged & -40 & 150 & 51 & 38 & 10 \\
\hline PVD1000u & $\gamma$-quench only & 25 & 144 & 28 & 24 & 10.6 \\
\hline PVD1000u & $\gamma$-quenched and aged & 25 & 137 & 69 & 20 & 11.9 \\
\hline PVD1000u & $\gamma$-quenched and aged & -40 & 164 & 69 & 20 & 12 \\
\hline Wrought & $\gamma$-quenched and aged & 25 & 126 & 65 & 34 & 10.5 \\
\hline Wrought & $\gamma$-quenched and aged & -40 & 148 & 67 & 33 & 11.1 \\
\hline
\end{tabular}

Testing of PVD Samples from Current Runs (Mars \#5, \#6, \#7, and \#9) -- Metallurgic analyses of most of the samples have been competed showing: a solid deposit from \#5 with sharp layers of banding, but a porous \#6 deposit. Samples \#7 and \#9 were solid deposits thick enough for mechanical testing. \#7 was obtained at $700^{\circ} \mathrm{C}$ with bias voltage at $0.15 \mathrm{KV}$ and enhanced ionization of $8 \%$. \#9 yielded two samples on separate substrates at 600 and $700^{\circ} \mathrm{C}$ with no bias. Analyses of \#9 samples were incomplete. 


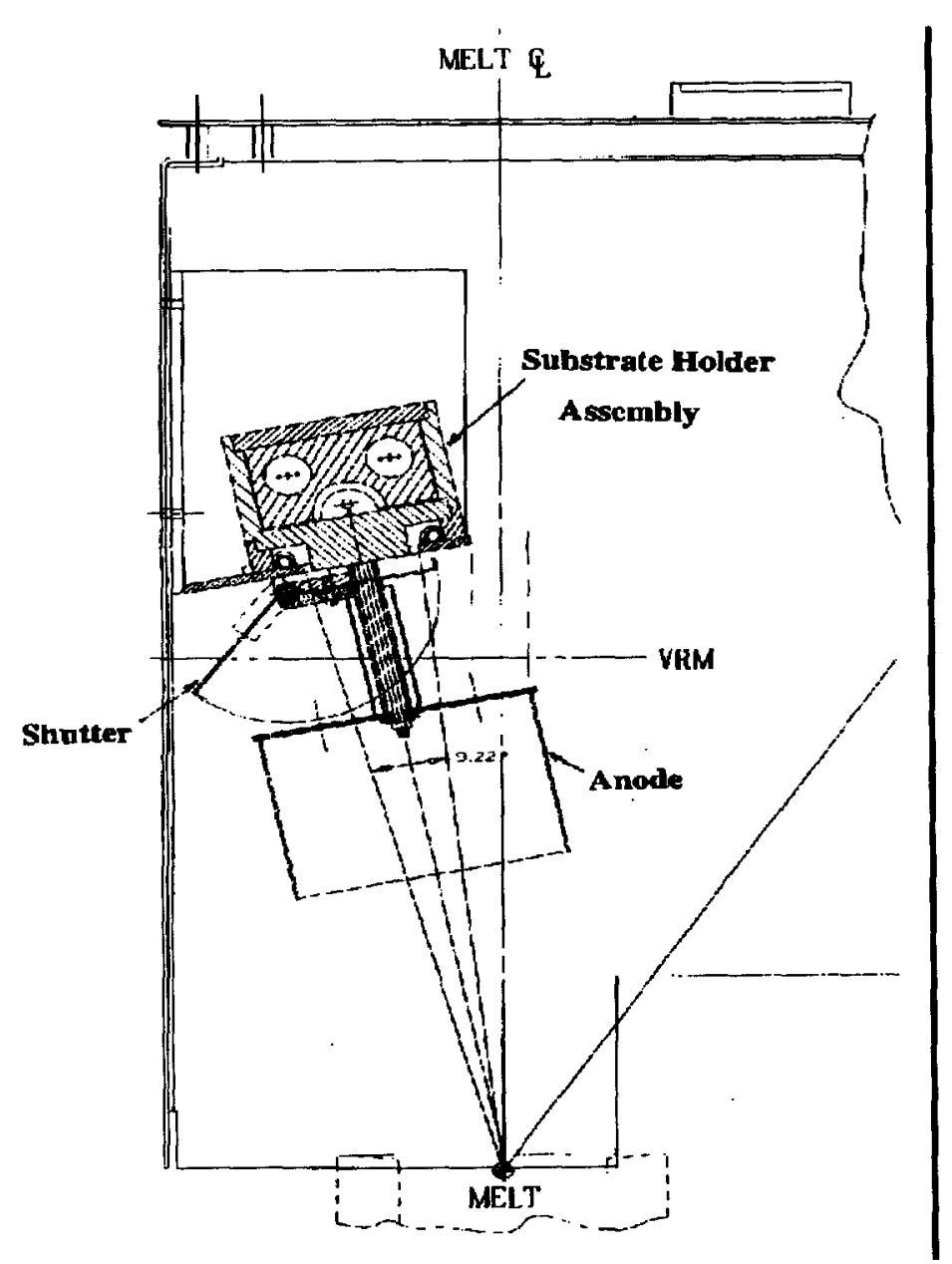

Figure 1 PVD Layout with Substrate Assembly and Ion-Enhancement Anode

Run \#7 showed a very solid deposit with layers of sharp banding with columnar structure, similar to that of run \#6 and 1000 u of run \#3. The tensile specimens from run \#7 were heat treated (Gamma-quenched and aged) and tensile tested. They exhibited equivalent strength and ductility as the wrought-processed material (with strength of $130 \mathrm{ksi}$ and $32 \%$ ductility).

\section{A.3 Observations and Conclusions for PVD Process}

We have characterized a wide range of process variables and broadened our PVD data base for U-6 Nb forming, with the following observations:

1. Good deposits can be obtained:

- $580^{\circ} \mathrm{C}$, biased

- $700^{\circ} \mathrm{C}$, biased and ion-enhanced

- $900^{\circ} \mathrm{C}$ and $1050^{\circ} \mathrm{C}$, unbiased

2. questionable deposits:

- $600^{\circ} \mathrm{C}$ and $700^{\circ} \mathrm{C}$, unbiased

- analysis not complete

3. Failed deposits:

- $350^{\circ} \mathrm{C}$, biased

- $450^{\circ} \mathrm{C}$ and $480^{\circ} \mathrm{C}$, unbiased

We conclude that the optimum PVD conditions have not been established. 
Other process conditions, however, were established for the current melt chamber setup:

- adequate E-gun current is to be $4-6$ amps at $35 \mathrm{kv}$

- maximum sustainable current the ion enhancement anode is $400 \mathrm{amp}$ at $40 \mathrm{v}$

- manual controls of E-gun and feed are adequate

- substrate temperature is a function of location and E-gun power.

For future experiments, the deposition process variables can be improved with the following:

- a better substrate temperature control by using active heating and cooling, use of shutter and gun power adjustment.

- use of a close deposit surface temperature monitoring

- a close control of vapor flux between runs

- an better feed ingot conditioning to ensure deposit quality, and

- a better substrate surface finish definition

In conclusion, we have found that

- high purity, fully dense and fine grained materials can be consistently produced

- material property refinement can be made through PVD process and subsequent heat treatment

- heat treatment is critical

- tensile properties of PVD materials are comparable to those of wrought-processed material, based on the static testing results. 


\section{B.1 KEM Experiments}

A schematic of the KEM system is shown in Figure 2. It consists of a supersonic nozzle for driving micron size particles to speeds in excess of $300 \mathrm{~m} / \mathrm{s}$ and a recovery hood for recovering the over-sprayed powder. The gas source used two K-bottles of commercial grade helium and nitrogen, regulated to nozzle inlet pressures of 500 psig or less. The fluidizing gas pressure driving the feeder was regulated to a $\Delta \mathrm{p}$ of $20-30$ psig above the process line

The test matrix consists of the following parameters with a wide range of values: powder materials, powder sizes (commercial grades), carrier gases (Helium and Argon), pressures, and substrate materials based on hardness, deposition thickness: thin film and bulk samples, as summarized in Table B1.

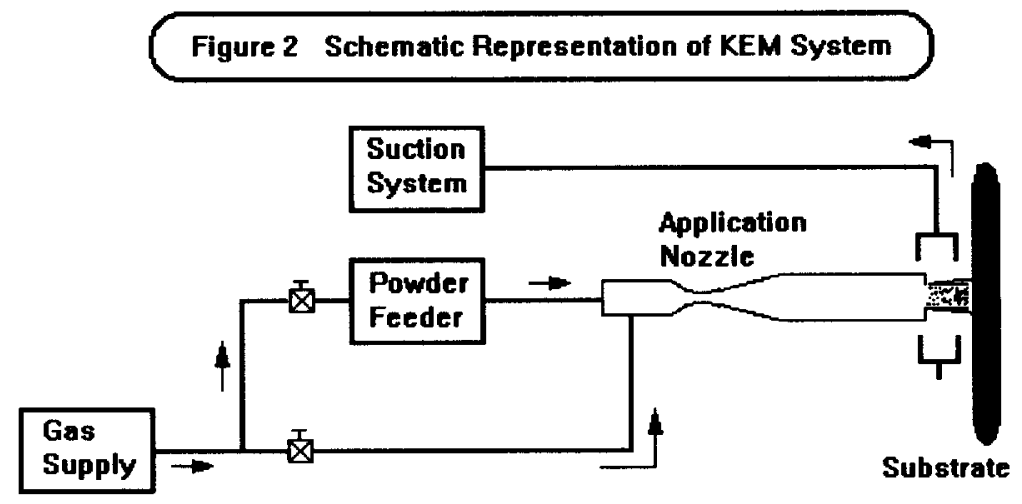

Table B1

\begin{tabular}{|l|l|l|l|}
\hline Powder Material & Substrate & Gas Pressure & Data \\
\hline $\mathrm{Cu}:<10$ and $<45 \mu \mathrm{m}$ & $\mathrm{Al}$ & He: $100,200,450 \mathrm{psig}$ & $\begin{array}{l}\text { thin coating: deposition rates, } \\
\text { hardness, metallograph }\end{array}$ \\
\hline $\mathrm{Cu}:<10 \mu \mathrm{m}$ & $\mathrm{Ni}$ & He: $450 \mathrm{psig}$ & $\begin{array}{l}\text { thin coating: hardness and } \\
\text { metallograph }\end{array}$ \\
\hline $\mathrm{Zn}:<10$ and $<45 \mu \mathrm{m}$ & $\mathrm{Al}$ & He: $100,200,450 \mathrm{psig}$ & $\begin{array}{l}\text { thin coating: deposition rates, } \\
\text { hardness; metallograph }\end{array}$ \\
\hline $\mathrm{Al}:<10$ and $<45 \mu \mathrm{m}$ & $\mathrm{Al}$ & He: $100,200,450 \mathrm{psig}$ & $\begin{array}{l}\text { thin coating: hardness and } \\
\text { metallograph }\end{array}$ \\
\hline $\mathrm{Ni}:<3 \mu \mathrm{m}$ & $\mathrm{Al}$ & He: $450 \mathrm{psig}$ & $\begin{array}{l}\text { thin coating: hardness and } \\
\text { metallograph }\end{array}$ \\
\hline $\mathrm{Ti}:<45 \mu \mathrm{m}$ & $\mathrm{Al}$ & He: $450 \mathrm{psig}$ & $\begin{array}{l}\text { thin coating: hardness and } \\
\text { metallograph }\end{array}$ \\
\hline $\mathrm{Cu}<10 \mu \mathrm{m}$ & $\mathrm{Al}$ & He: $450 \mathrm{psig}$ & $\begin{array}{l}\text { bulk sample: metallograph, } \\
\text { heat treatment, hardness, and } \\
\text { mechanical testing }\end{array}$ \\
\hline $\mathrm{Zn}<10 \mu \mathrm{m}$ & $\mathrm{Al}$ & He: $450 \mathrm{psig}$ & $\begin{array}{l}\text { bulk sample: hardness and } \\
\text { metallograph }\end{array}$ \\
\hline $\mathrm{Ti}<45 \mu \mathrm{m}$ & $\mathrm{Al}$ & He: $450 \mathrm{psig}$ & $\begin{array}{l}\text { bulk sample: metallograph, } \\
\text { heat treatment, and hardness }\end{array}$ \\
\hline
\end{tabular}




\section{B.2 KEM Results and Discussions}

The thickness of the samples varies with the powder size and operating parameters. For example, up to $2.5 \mathrm{~mm}$ thick KEM deposition can be obtained with longer dwell time, smaller powder size and higher inlet pressure. Figure 3 compares the average deposition rates of $\mathrm{Cu}$ and $\mathrm{Zn}$ on $\mathrm{Al}$ substrate, in microns per second per $\mathrm{cm}^{2}$, as a function of helium gas inlet pressure in psig, particle size, and depositing powder. These values are representative of the current KEM laboratory configuration consisting of a modified Metco powder feeder and a ITI-designed nozzle.

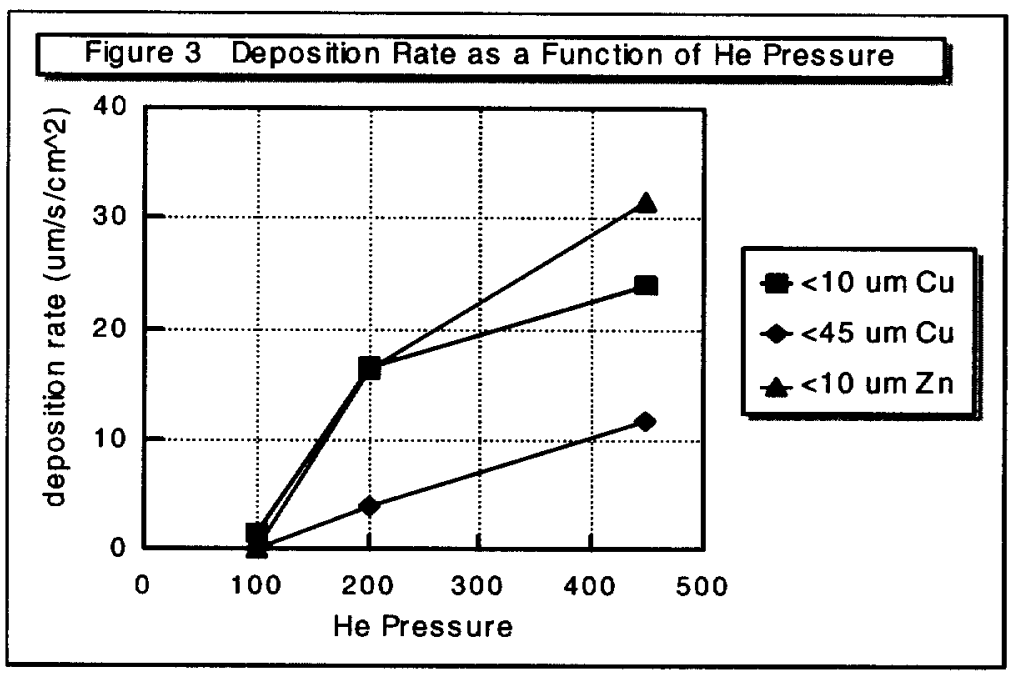

Comparison of deposition rates between different powders, e.g., $\mathrm{Cu}$ and $\mathrm{Zn}$, can be difficult due to the effects of the feeder on the flow of powders. The large uncertainties associated with the deposition rates were attributable to powder flow rate variations that were highly dependent on the powder properties and the feeder behavior. Generally, higher inlet pressures and smaller particles, tended to increase the deposit rates, and samples with lower porosities and higher hardness. A few selected KEM depositions of various powders were made on substrates of copper and nickel.

The hardness measurements for $\mathrm{Cu}$ on $\mathrm{Al}$ and $\mathrm{Zn}$ on $\mathrm{Al}$ showed that the hardness tends to be slightly higher at the higher gas pressure for thicker spray-form buildup.

Table B2 summarizes the results for deposit on aluminum substrates, showing the effects of powder size, shape and gas pressure on the deposition rate, porosity, and hardness.

Table B2

\begin{tabular}{|c|c|c|c|c|c|}
\hline Powder & $\begin{array}{l}\text { Avg. Deposition } \\
\text { Rate }\left(\mu \mathrm{m} / \mathrm{cm}^{2}-\mathrm{s}\right)\end{array}$ & Helium Gas (psig) & Porosity & $\begin{array}{l}\text { Hardness } \\
\text { RH, 15T }\end{array}$ & Base Metal RH \\
\hline $\begin{array}{l}\mathrm{Al}(<10 \mu \mathrm{m}) \\
\mathrm{Al}(<10 \mu \mathrm{m})\end{array}$ & $\begin{array}{r}13 \pm 7 \\
6 \pm 5 \\
\end{array}$ & $\begin{array}{l}200 \\
450\end{array}$ & $\begin{array}{l}<5 \% \\
<5 \%\end{array}$ & $\begin{array}{l}71 \pm 2 \\
72 \pm 2\end{array}$ & $77 \pm 2$ \\
\hline $\begin{array}{l}\mathrm{Al}(20 \mu \mathrm{m}), \mathrm{sph} \\
\mathrm{Al}(20 \mu \mathrm{m}), \mathrm{sph}\end{array}$ & $\begin{array}{r}99 \pm 20 \\
384 \pm 20 \\
\end{array}$ & $\begin{array}{l}200 \\
450\end{array}$ & $\begin{array}{l}5-10 \% \\
5-10 \%\end{array}$ & $\begin{array}{l}61 \pm 4 \\
64 \pm 3 \\
\end{array}$ & \\
\hline $\begin{array}{l}\mathrm{Cu}(<10 \mu \mathrm{m}) \\
\mathrm{Cu}(<10 \mu \mathrm{m}) \\
\mathrm{Cu}(<10 \mu \mathrm{m})\end{array}$ & $\begin{array}{c}8 \pm 3 \\
84 \pm 17 \\
122 \pm 23\end{array}$ & $\begin{array}{l}100 \\
200 \\
450 \\
\end{array}$ & $\begin{array}{l}<5 \% \\
5.6 \pm 4.5 \\
<5 \% \\
\end{array}$ & $\begin{array}{l}77 \pm 3 \\
85 \pm 2 \\
89 \pm 2 \\
\end{array}$ & $76 \pm 1$ \\
\hline $\begin{array}{l}\mathrm{Cu}(<45 \mu \mathrm{m}) \\
\mathrm{Cu}(<45 \mu \mathrm{m})\end{array}$ & $\begin{array}{l}20 \pm 1 \\
59 \pm 6\end{array}$ & $\begin{array}{l}200 \\
450 \\
\end{array}$ & $\begin{array}{l}>10 \% \\
>10 \%\end{array}$ & $\begin{array}{l}76 \pm 2 \\
78 \pm 3 \\
\end{array}$ & \\
\hline $\begin{array}{l}\mathrm{Ni}(<3 \mu \mathrm{m}) \\
\mathrm{Ni}(<3 \mu \mathrm{m})\end{array}$ & $\begin{array}{l}14 \pm 5 \\
23 \pm 12\end{array}$ & $\begin{array}{l}200 \\
450\end{array}$ & - & $\begin{array}{l}88 \pm 2 \\
87 \pm 2\end{array}$ & $\begin{array}{l}87 \pm 1 \\
\text { (Inconel-600) }\end{array}$ \\
\hline
\end{tabular}




\begin{tabular}{|l|c|l|l|l|l|}
\hline $\mathrm{Ni}(<10 \mu \mathrm{m})$ & $13 \pm 4$ & 200 & $5-10 \%$ & $88 \pm 4$ & \\
$\mathrm{Ni}(<10 \mu \mathrm{m})$ & $44 \pm 7$ & 450 & - & $92 \pm 1$ & \\
\hline $\mathrm{Ti}(<45 \mu \mathrm{m})$ & $29 \pm 7$ & 200 & $18 \pm 4.5$ & $78 \pm 3$ & $80 \pm 1$ \\
$\mathrm{Ti}(<45 \mu \mathrm{m})$ & $42 \pm 13$ & 450 & $>10 \%$ & $83 \pm 6$ & \\
\hline $\mathrm{Zn}(<10 \mu \mathrm{m})$ & $82 \pm 8-160 \pm 44$ & $200-450$ & $<5 \%$ & $63 \pm 4$ & \\
$\mathrm{Zn}(10-25 \mu \mathrm{m})$ & $15 \pm 6-20 \pm 3$ & $200-450$ & $<5 \%$ & $58 \pm 4$ & \\
\hline
\end{tabular}

Micrographic comparison of the particle size effects showed that the bulk and interfacial porosities were quite low (less than $5 \%$ ) for the $<10 \mu \mathrm{m}-\mathrm{Cu}$, while the $<45 \mu \mathrm{m}-\mathrm{Cu}$ exhibited moderate porosity (10-15\%). The micrograph of a "Cu-on-Cu" deposit showed a much lower level of interfacial porosity, as compared to a " $\mathrm{Cu}$-onAl" deposit under otherwise the same conditions, suggesting that similar metals form stronger bonding than the dissimilar ones.

ITI generated the bulk (thick) samples ( $\mathrm{Cu}, \mathrm{Ti}$, and $\mathrm{Zn}$ ) [Table B3] using the parameters derived from the test matrix. All KEM bulk samples were fairly rough on the deposition side because of manually operated nozzle translation. The $\mathrm{Cu}$ and $\mathrm{Ti}$ bulk samples exhibited significant residual stress that resulted in bending of the samples. The zinc sample showed much less residual stress.

Table B3 Bulk sample deposition parameters:

\begin{tabular}{|c|c|c|c|}
\hline Bulk Sample & $\mathrm{Cu}$ & $\mathrm{Ti}$ & $\mathrm{Zn}$ \\
\hline Dimension & $8.0 \mathrm{~cm} \times 1.6 \mathrm{~cm} \times 0.6 \mathrm{~cm}$ & $8.0 \mathrm{~cm} \times 1.7 \mathrm{~cm} \times 0.5 \mathrm{~cm}$ & $8.0 \mathrm{~cm} \times 1.8 \mathrm{~cm} \times 0.3 \mathrm{~cm}$ \\
\hline Powder Size & $<10 \mu \mathrm{m}$ & $<45 \mu \mathrm{m}$ & $<10 \mu \mathrm{m}$ \\
\hline $\begin{array}{c}\text { Helium } \\
\text { Pressure }\end{array}$ & $300 \mathrm{psig}$ & $250 \mathrm{psig}$ & $300 \mathrm{psig}$ \\
\hline $\begin{array}{c}\text { Height of } \\
\text { Curvature }\end{array}$ & $3.0 \mathrm{~mm}$ & $2.5 \mathrm{~mm}$ & $0.5 \mathrm{~mm}$ \\
\hline $\begin{array}{c}\text { Radius of } \\
\text { Curvature }\end{array}$ & 34 & 32 & 203 \\
\hline
\end{tabular}

Table B4 Bulk samples test summary

\begin{tabular}{|c|c|c|c|c|c|c|}
\hline & Treatment ${ }^{(1)}$ & $\begin{array}{c}\text { Rockwell } \\
\text { Hardness }^{(2)} \\
\end{array}$ & Density & $\begin{array}{c}\text { Tensile } \\
\text { Property }\end{array}$ & Machineability & Oxygen Content \\
\hline $\mathrm{Cu}$ & $\begin{array}{l}\text { - As-deposited } \\
\text { - Annealed }\end{array}$ & $\begin{array}{l}87(15 T) \\
80(15 T)\end{array}$ & $\begin{array}{l}94 \% \\
96 \%\end{array}$ & $\begin{array}{c}38 \mathrm{ksi} \\
0.7 \% \\
\text { (ultimate) }\end{array}$ & $\begin{array}{l}\text { poor } \\
\text { good }\end{array}$ & $\begin{array}{l}0.209 \% \pm 0.057- \\
\text { comparable to general } \\
\text { MSDS spec. for } \mathrm{Cu} \\
\text { powders }\end{array}$ \\
\hline $\mathrm{Ti}$ & $\begin{array}{l}\text { - As-deposited } \\
\text { - Annealed } \\
\text { - HIP'ed }\end{array}$ & $\begin{array}{r}82(15 \mathrm{~T}) \\
32(\mathrm{C}) \\
38(\mathrm{C})\end{array}$ & $\begin{array}{c}82 \% \\
93 \% \\
100 \%\end{array}$ & $\begin{array}{l}-- \\
-- \\
--\end{array}$ & $\begin{array}{l}\text { poor } \\
\text { poor-fair } \\
\text { fair }\end{array}$ & $\ldots$ \\
\hline $\mathrm{Zn}$ & - As-deposited & $74(15 T)$ & $96 \%$ & $\cdots$ & fair & -- \\
\hline
\end{tabular}

(1). Annealing condition: $2 / 3$ melting temperature 3 hours; HIP condition: $15 \mathrm{ksi}$ at $1000^{\circ} \mathrm{C} 3$ hours.

(2). $[15 \mathrm{~T}]$ is Rockwell superficial hardness: $\max$. scale $=92.5$ equivalent to 19.9 on $[\mathrm{C}]$ scale.

The post-KEM processes included annealing of $\mathrm{Cu}$ sample, and annealing followed by HIP-ing of Ti sample. These treatments greatly improved the deposits mechanical properties. Table 4 is a summary of the analysis and testing results.

Annealing of KEM-deposited $\mathrm{Cu}$ had moderate reduction in porosity, (from $6 \%$ to $4 \%$ ), and a slight decrease in hardness. Annealing and HIP-ing of the KEM-deposited Ti reduced the porosity from $17 \%$ to 0 , increased the hardness greatly.

A tensile specimen machined from an annealed $\mathrm{Cu}$ sample was tested. The result shows that, with $38 \mathrm{ksi}$ ultimate stress at $0.75 \%$ elongation, the specimen was brittle but relatively strong. 
Elemental analysis of the $\mathrm{Cu}$ sample shows that the bulk oxygen content was in line with the level of commercial grade $\mathrm{Cu}$ powders, that the KEM process failed to purge out the oxide coating naturally occurring on the $\mathrm{Cu}$ particle surfaces.

\section{B.3 KEM Summary}

This study has demonstrated that it is feasible to use KEM process to deposit a wide range of metal powders to form both thin and thick coatings on various substrates. The work also has validated KEM as an efficient method for spraying fine reactive and pyrophoric powders such as titanium, in an inert gaseous atmosphere without using high vacuum deposition technology.

Post KEM processes such as annealing and/or HIP-ing will greatly improve the mechanical properties of the KEM-produced free-standing components. For refurbishment or thin coating applications the post-processes may not be as important.

The effect of the measured residual oxide on the KEM material property is not well understood. But it does suggest that powder conditioning and/or in-situ generation of powder as an integral part of the KEM process should be studied.

We have made preliminary modeling analyses of the KEM phenomena, and the results obtained to date reveal that impacts by solid particles at high velocities could cause deformations on both the incident particles and the target and that the deformation in the latter material is qualitatively similar to that seen in the test samples. A more detailed analysis of this work has been reported in: Final Report - FY96 Manufacturing Technology Thrust Area (DTED - A1-961016-CCya).

\section{Future Work}

The proposed work for PVD and KEM should be separate:

PVD -

- optimizing the PVD process and post process variables

- forming and characterizing small cylindrical hydro-test specimens

- performing hydro-test

- studying other post-process treatments to optimize or tailor material property

- studying PVD process scale-up: geometry discontinuity and substrate design

- assessing weldability of the heat treated PVD alloy for microstructure and KEM mechanical strength

- carrying out particle-target interaction experiments

- U6 Nb experiments

- powder synthesis and conditioning

- post-KEM processes

- process modeling analysis 


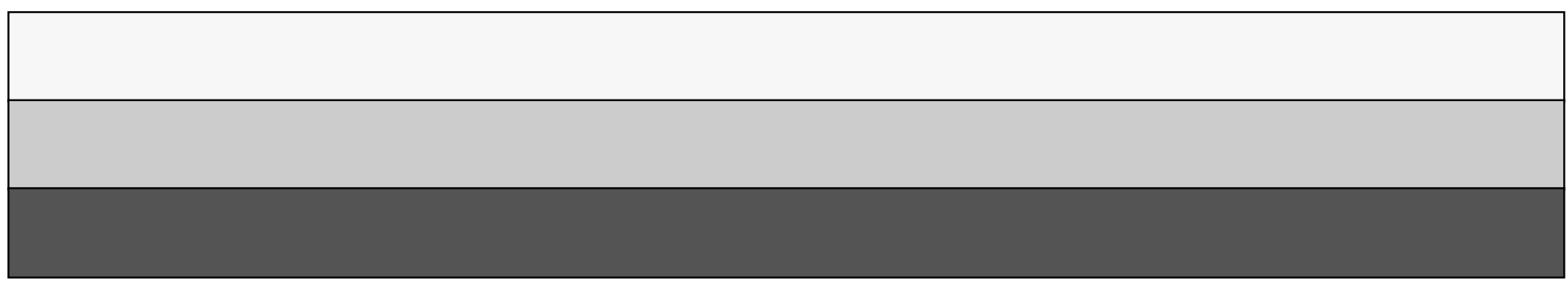

